in press: The American Journal of Psychology

Running head: Twilight

\title{
Twilight of Rationality
}

Review of 'The bias that divides us:

The science and politics of myside thinking'

by Keith E. Stanovich

Joachim I. Krueger

Brown University

2,224 words of text

(excluding references)

Correspondence:

Joachim I. Krueger

Department of Cognitive, Linguistic \& Psychological Sciences

Brown University

190 Thayer St.

Providence, RI 02912

Phone: (401) 863-2503

Home page: http://research.brown.edu/research/profile.php?id=10378

Keywords: bias, rationality, tribalism, activism

Note: This book is published by MIT Press, Cambridge, MA, 2021.

ISBN 9780262045759, list price: \$33.57, 256 pages, hardcover. 
If you really think about it, you cannot but conclude that Marx was right.

- A well-meaning fellow student trying to introduce JIK to the mysteries of the closed mind. East of the University of Bielefeld, October 1977

The great error of individualistic psychology is the supposition that man thinks.

- Gumplowicz (1899, p. 156)

Oliver Cromwell, after the Battle of Dunbar in 1650, wrote to the Scots "I beseech you, in the bowels of Christ, think it possible that you may be mistaken." Few remember what Cromwell asked his British brethren to change their minds about, but the eminent British Bayesian Dennis Lindley (1973) elevated his plea to a statistical rule. Eschew priors of 1 and 0 , lest you forfeit the benefits of evidence. Eschew certainty and keep your mind, at least a crack, open.

In The Bias That Divides Us, Keith Stanovich takes us to task for not doing this. If the lack of mental openness were a mere private affair, things would be bad enough, but things are worse because the closed mind is groupish, or, to use a fashionable term, tribal. Not only do many of us hold fast to false, immoral, or untestable beliefs, or beliefs that have all these features, but we do so in ways that make these beliefs predictable from the groups with which we associate and pay allegiance to. As the members of other groups do the same, the ground is prepared for conflict, and not just between the English and the Scots.

Stanovich calls this bias "myside bias" although the term "partisan bias" might be more apt because it highlights its tribal nature better than the chosen term. Stanovich's book is a tour de force of scientific analysis, inference, and argument. The reader might come away from reading it shaken. As hard it is to determine the bias's epistemic irrationality, and as it is even harder to determine its instrumental irrationality, the more one wonders where hope may be found. If a large section of the population and the institutions that are supposed to serve them are so dug into the depths of Myside Bias (hereafter MB), how might we attain 
enlightenment? Stanovich himself has dedicated much of his distinguished career to the teaching of clear thinking (Stanovich, 2012) and the reduction of cognitive biases through education. Now the MB has exploded on the scene as a super-bias, which, much like a supervirus, has found a way to survive, replicate itself, and poison the minds of those who are not even aware of the disease.

Stanovich takes the reader on a journey where in six chapters he methodically makes his case in a way that is itself a fine example of how MB can be held at bay. Each chapter tackles a specific question and Stanovich shows great discipline to make clear what he claims and what the boundaries of his claims are. It is well to review the core messages of these chapters in sequence.

Chapter 1 provides examples of MB, where the famous work by Hastorf and Cantril (1954) and Lord, Ross, and Lepper (1979) serves to remind us how easily we see and remember that which confirms our pre-existing views. MB is complex in that it involves multiple psychological process and produces multiple types of psychological outcomes. By carefully distinguishing MB from seemingly related biases such as certain kinds of confirmation bias (i.e., the positive testing strategy) and belief bias, Stanovich guards against any sloppy lumping of self-serving irrationality under the same roof. MB proper hinges on distal, that is untestable, beliefs held with conviction and emotional investment. It is here where rationality breaks down because reason has no response to axiomatic and affect-laden worldviews. They lie outside of its province.

Yet, Stanovich shares the view that reason has evolved, at least in part, as an adaptation to the need to persuade others. If so, how has the MB evolved? One possibility is that a display of great conviction serves as a cue to argument strength; another is that for the 
target of a persuasion attempt the same sort of conviction serves as a protection against unwanted social influence. If opposing convictions slip into an arms race where each seeks to grow stronger faster than the other, we find what Stanovich bemoans as the "tragedy of the communication commons." This tragedy is amplified by our reasonable need to avoid the psychic costs that come with gathering information, thinking, and changing our minds (Krueger et al., 2021).

Chapter 2 tackles the question of whether, or under what conditions, MB is irrational. Here, Stanovich goes beyond Lindley's proscription of priors that have no variance (0 and 1). Using a three-decade old proof, Stanovich shows that priors may inform and change likelihood ratios, that is, the evaluator's assessment of the evidence. Reasonable people may disagree on what the evidence shows and they may reasonably end up with more polarized beliefs. Polarization is unreasonable only if people assimilate the evidence to untested, untestable, or epistemically remote convictions. It is not easy to determine whether these restrictive conditions are met, and Stanovich expresses some nervousness over the possibility that rationality might dissolve as a tractable construct. There is, however, a useful heuristic. Besides asking whether a prior belief is remote and protected, one can ask how central it is the person's network of beliefs. It is reasonable to be a belief conservative if a change in the challenged belief would require the overturning of a very large number of related beliefs in order to keep the network coherent. This is why many experimental psychologists refused to believe Bem's (2011) finding that mental events can causally influence their own past, and the low $p$ values be damned (Fiedler \& Krueger, 2012).

The last refuge of MB is its instrumental rationality. Even despicable goals can be pursued with rational coherence and utility maximization. Certain Nazis, as some 
distinguished psychologists have suggested, may have been nuts without being irrational. Likewise, MB can serve group cohesion, which can be a treasured goal. "Hence," as Stanovich puts it, "we will quite naturally have a myside bias toward the group's central beliefs" (p. 48). This insight vindicates Ludwig Gumplowicz's (1899) sociology of mind. MB fosters a group mind with the individual group members remaining unaware that their deepest convictions are not the products of their personal reflection, but are predicted, and arguably caused, by their embeddedness in belief tribes. In the tragedy of the communication commons others pay the price for our MB, first the members of other groups, but ultimately all of us. Hence the tragedy.

Chapter 3 is for the most part a parade of null events. MB does not correlate with most established measures of intelligence, cognitive functioning, or personality. This is noteworthy because most other thinking biases do. This makes MB an odd bias by the lights of the traditional paradigm, to which Stanovich himself has made so many contributions. We must resist the temptation to attribute $\mathrm{MB}$ to the dull and the lazy. In fact, $\mathrm{MB}$ is more prevalent among the so-called cognitive elites. The caveat here is that the cognitive elites succumb to MB selectively, that is, in domains where they have cherished convictions. Strong convictions are the mark of ideology, and they beget a belief superiority bias. If I hold a belief with great fervor and certainty, I am liable to think that my belief is better and truer than yours. The law of regression demands it (Fiedler \& Krueger, 2013). Importantly, the type of content of the ideology does not matter, only that it is an ideology. MB is an equalopportunity bias, an idea Stanovich brings to fruition the last three chapters.

Chapter 4 explores the origins of $\mathrm{MB}$ and the dynamics of its survival. Besides noting the role of social learning, which is group based, Stanovich now takes aim at precisely 
that cognitive elite that should know best how to identify MB in others and how to guard against it in their own research of those others. Alas, decades of research of subtle intergroup bias has been tainted by liberal contents such that a test taker would receive a high score on, say, a racism scale in part by endorsing politically conservative views. Such measurement instruments obscure intolerance on the political left. Recent research that has corrected these measurement biases shows that ideologies and their content predict outgroup prejudice. In other words, research on subtle racism has itself been infected by MB.

In good Neo-Gumplowiczian manner, Stanovich asks rhetorically "What if you don't own your beliefs, but instead, they own you?" (p. 81), and by now the reader is ready for 'Cultural Replicator Theory.' These nasty convictions that beget MB, so the theory, are selfreplicating memes that may on a good day support instrumental rationality and get us what we want (while hurting others), but otherwise are along for their Darwinian ride towards immortality as junk memes in a metaphorical and disembodied DNA. Here, Stanovich flirts with the fallacy of reification, but is saved by the statistical models that allow us to 'compute' the journey of these memes.

How does one fight Darwinian logic? Stanovich's last stand is to appeal to the better angels of our rational minds. We shall, he proclaims, "distance ourselves from our convictions" (p.89), and muster "the principles of scientific inference and rational thought [which] serve essentially as meme evaluation devices that help us determine which of our beliefs are true and therefore probably of use to us" (p. 92). We are back to the dual-systems logic, where the rational System 2 overcomes the follies of the intuitive System 1. The trouble is that for much of the book Stanovich has already shown that there is little hope for this strategy in the world of the MB. 
Chapter 5 goes full throttle after the MB excesses among progressive academic elites in psychology. Here, Stanovich can scarcely hide his anger and disappointment. Psychology, he claims, has become an ideological monoculture and has thus betrayed the ideal of the hardnosed pursuit of the truth, wherever it may lead us. He has a point. Many progressive psychologists see no problem with placing activism alongside truth-seeking, and some favor the former. Doing that, they bake MB into their professional work and thus corrupt it. Many activist convictions are precisely the sort of memes that are protected from challenge; the unwary challenger is easily branded an offender and enemy, not on evidentiary grounds but on asserted moral grounds. The Reverend Bayes has left the building.

In the hands of these elites, the science of psychology degenerates into paternalism. The charge of 'false consciousness,' leveled by Friedrich Engels (1893/1968), raised by Herbert Marcuse (1965), and introduced to empirical psychology by John Jost (Jost \& Banaji, 1995) is exemplary. The poor and the uneducated, so the argument goes, do not know what is good for them. They support a system that oppresses them. Elites understand what is really going on and they can help fix it for the poor if only the poor changed their beliefs and followed these elites. The possibility that the poor might have their own preferences and beliefs that they are interested in protecting does not seem to enter the calculus.

This bleak picture leaves little room for remedial action. Undeterred, Stanovich elaborates in chapter 6 beyond the appeal to more System 2 thinking. Along the way, he fires parting shots at the academic left. "Universities," he asserts, "have totally abdicated their responsibility to be neutral, unbiased arbiters of evidence on controversial issues" (p. 126). They have surrendered to identity politics, which play "a toxic role [.. . ] in cultural and political discourse" (p. 152). This is heavy. Memes of identity assertion become arguments 
and lived experience trumps collected evidence. Progressive memes no longer need to compete with reason; they claim primacy by fiat. The American Psychological Association does its part. "APA apologizes to communities of color for longstanding contributions to systemic racism" the association announced on October 29, 2021, and promises to lead the fight against systemic racism (APA, 2021). The Society for Experimental Social Psychology is not far behind, but it took a mini-scandal to stir it into action. Steve Stroessner, SESP's executive officer, announced on November 12, 2021, that the society would prepare a statement on equity, diversity, and inclusion and ask all future conference speakers to be mindful of it when preparing their remarks. The demand to endorse such a statement or be excluded is only a step away. Sensible but unwritten norms of tact, decency, and common sense are no longer deemed sufficient when memes control thinking by instilling fear.

What is chilling here that certain memetic standpoints are regarded as revealed truth and used to compel compliance and public self-criticism. They brand the questioner a heretic before the questioner has spoken. MB reinforces the self-righteousness of a determined activist group. When resistance is futile, disengagement remains a last resort. Almost refreshingly, Stanovich's last piece of advice is to detach from the cognitive elites and do as the nonelites do. "Go ahead and be 'inconsistent' from your party's point of view" (p. 142). Disaggregate the bundle of convictions they feed you and make up your own mind, one issue at a time. And if the resulting beliefs, temporary and changeable as they may be, do not perfectly cohere, enjoy your state epistemic flow. There's wisdom in it.

\section{References}

American Psychological Association (2021). Addressing racism. https://www.apa.org/about/apa/addressing-racism, retrieved November 12, 2021. 
Bem, D. J. (2011). Feeling the future: Experimental evidence for anomalous retroactive influences on cognition and affect. Journal of Personality and Social Psychology, 100, 407435 .

Engels, F. (1893/1968). Letter to Franz Mehring. In Marx and Engels correspondence. International Publisher. Online text retrieved on November 13, 2021 from https://www.marxists.org/archive/marx/works/1893/letters/93 07 14.htm

Fiedler, K., \& Krueger, J. I. (2012). More than an artifact: Regression as a theoretical construct. In J. I. Krueger (Ed.). Social judgment and decision-making (pp. 171-189). Psychology Press.

Fiedler, K., \& Krueger, J.I. (2013). Afterthoughts on precognition: No cogent evidence for anomalous influences of consequent events on preceding cognition. Theory \& Psychology, $23,323-333$.

Gumplowicz, L. (1899). The outlines of sociology. American Academy of Political and Social Science.

Hastorf, A. H., \& Cantril, H. (1954). They saw a game: A case study. Journal of Abnormal and Social Psychology, 49, 129-134.

Jost, J. T., \& Banaji, M. R. (1994). The role of stereotyping in system-justification and the production of false consciousness. British Journal of Social Psychology, 33, 1-27.

Krueger, J. I., Hahn, U., Ellerbrock, D., Gächter, S., Hertwig, R., Kornhauser, L. A., Leuker, C., Szech, N., \& Waldmann, M. R. (2020). Normative implications of deliberate ignorance. In R. Hertwig \& C. Engel (Eds.) Deliberate ignorance: Choosing not to know. Strüngmann Forum Reports, 29, 257-287. MIT Press.

Lindley, D. V. (1973). Making decisions. Wiley.

Lord, C. G., Ross, L., \& Lepper, M. R. (1979). Biased assimilation and attitude polarization: The effects of prior theories on subsequently considered evidence. Journal of Personality and Social Psychology, 37, 2098-109.

Marcuse, H. (1965). Repressive tolerance. In R. P. Wolff, B. Moore Jr., \& H. Marcuse, A critique of pure tolerance. Beacon Press.

Society for Experimental Social Psychology (2021). An important message from the SESP executive committee. Email to members. Received November 12, 2021.

Stanovich, K. E. (2012). How to think straight about psychology. $10^{\text {th }}$ ed. Pearson. 